\title{
Layanan Konseling Kelompok dalam Meningkatkan Resiliensi Anak Korban Banjir
}

\author{
Neneng Ririn Meidina Rachmat* \\ Jurusan Bimbingan dan Konseling Islam, UIN Sunan Gunung Djati, Bandung \\ *Email : ririnmeidina03@gmail.com
}

\begin{abstract}
ABSTRAK
Penelitian ini mengungkapkan tentang kondisi resiliensi anak korban banjir sebelum mengikuti konseling kelompok, konseling kelompok dalam meningkatkan resiliensi pada anak korban banjir, kondisi resiliensi anak korban banjir setelah mengikuti konseling kelompok di Baleendah. Metode yang digunakan dalam penelitian ini adalah metode deskriptif dengan menggunakan pendekatan kualitatif. Teknik pengumpulan data dilakukan melalui observasi, wawancara langsung dengan anak korban banjir, pembimbing/ konselor sekolah Rescue dan kepala sekolah Rescue, mengklarifikasi data dan menarik kesimpulan serta dokumentasi. Hasil yang didapat dalam penelitian ini menunjukkan bahwa layanan konseling kelompok yang dilakukan Sekolah Rescue di pengungsian Baleendah, memiliki hasil yang efektif dan sangat berpengaruh terhadap kondisi resiliensi anak-anak korban banjir di tempat pengungsian.
\end{abstract}

Kata Kunci : Konseling Kelompok; Resiliensi; Anak Korban Banjir.

\section{ABSTRACT}

The research explains about the resilience condition of flood victims before following group counseling, to increase the resilience of flood victim children after following the group in Baleendah. The method used in this research is descriptive by using qualitative approach. The technique of collecting data is done through observation, direct interview with children of flood victim, mentors/ school counselors of Rescue and headmaster of Rescue, clarify the data and the result of this research describes that group counseling services done by Rescue school in Baleendah evacuation, have an effective result and very influential on resilience condition of the children in the place.

Keywords: Group Counseling; Resilience; Flood Victim Children 


\section{PENDAHULUAN}

Indonesia merupakan negara kepulauan. Secara geografis Indonesia merupakan negara yang rawan untuk terjadinya bencana alam. Tak heran, hampir setiap tahun jika kita sering mendengar berita mengenai bencana alam yang terjadi di Indonesia. Mulai dari longsor, gempa bumi, tsunami, gunung meletus bahkan hingga banjir kerap terjadi di Indonesia. Akibatnya menyebabkan kerugian dan kerusakan yang dialami oleh manusia baik dari segi materi maupun dari segi psikologis bagi mereka yang tinggal diwilayah yang dilanda oleh bencana alam.

Jawa Barat merupakan salah satu wilayah di Indonesia yang paling sering mengalami bencana alam. Salah satunya adalah Baleendah, Kabupaten Bandung. Bencana alam yang seringkali dihadapi oleh masyarakat Baleendah adalah banjir. Setiap turun hujan, maka daerah ini akan terendam oleh air. Lebih-lebih jika intensitas curah hujan yang tinggi dan berdurasi lama, maka akan dipastikan banjir akan melanda wilayah Baleendah. Bencana banjir beresiko mengancam keselamatan jiwa para warga serta merusak infrastuktur yang ada. Bukan hanya kerugian secara materi yang menjadi masalah, namun juga dampak psikologis.

Bencana alam dapat memberikan "trauma" bagi orang-orang yang mengalaminya, itu dikarenakan mereka merasa kehilangan harta benda yang dimiliki, kehilangan anggota keluarga mereka, bahkan masih saja dihantui rasa takut saat hendak menyelamatkan diri sendiri dari bencana alam yang terjadi. Dampak trauma itu bukan hanya menimpa para orang dewasa tetapi juga menimpa para remaja bahkan anak-anak.

Menurut Ehreinreich sepertiga dari korban bencana adalah anak-anak. Hal ini dapat dipahami, karena dari jumlah populasi suatu masyarakat, anak-anak merupakan bagian dari populasi tersebut. Kejadian bencana juga akan mengakibatkan "trauma" psikologis bagi para penderitanya khususnya pada anak-anak. Dampak bencana berbeda-beda bagi setiap orang yang mengalaminya. Adapun beberapa faktor yang berpengaruh terhadap kerentanan seseorang sehingga beresiko terhadap bencana adalah semakin tinggi tingkat keparahan bencana dan tingkat kengerian pengalaman yang dialami semakin besar pula efek psikologis yang dirasakan (Ehreinreich, 2001: 25).

Bencana alam dapat memberikan dampak yang cukup parah bagi parakorban baik secara fisik, psikologis maupun secara sosial, sehingga perlu tindakan lebih lanjut dalam menangani penanggulangan bencana baik ketika bencana sedang terjadi maupun setelah bencana berakhir. Oleh karena itu, masyarakat perlu memiliki kemampuan untuk dapat melanjutkan hidup setelah mengalami tekanan yang berat akibat bencana alam atau dengan kata lain mereka harus mampu beradaptasi dan tetap teguh dalam situasi sulit, hal itu disebut 
dengan resiliensi (Taufiq, 2014: 74).

Menurut Reivich dan Shatte, menjelaskan bahwa resiliensi adalah kapasitas untuk merespon secara sehat dan produktif ketika berhadapan dengan kesengsaraan atau trauma, yang diperlukan untuk mengelola tekanan hidup sehari-hari. Resiliensi adalah kemampuan untuk mengatasi dan beradaptasi terhadap kejadian yang berat atau masalah yang terjadi dalam kehidupan. Konsep resiliensi dalam manajemen bencana telah ada dalam literatur sejak 1980-an namun menjadi sesuatu yang sangat populer dalam sepuluh tahun terakhir ini. Mengingat pentingnya resiliensi sebagai faktor untuk meraih keberlangsungan hidup bagi mereka yang terkena bencana. Resiliensi berperan sebagai strategi dalam beradaptasi menghadapi perubahan iklim dan persyaratan untuk bangkit dari bencana (Reivich, 2002: 2-3).

Bencana banjir yang melanda beberapa wilayah di Indonesia merupakan stressor kehidupan yang memerlukan proses adaptasi. Setidaknya di wilayah Kabupaten Bandung ada beberapa kecamatan yang terendam banjir yaitu Kecamatan Baleendah, Kecamatan Dayeuhkolot, Kecamatan Bojongsoang dan Kecamatan Banjaran. Ketinggian air berkisar $30 \mathrm{~cm}$ hingga $2 \mathrm{~m}$ merendam perumahan warga dan secara otomatis juga melumpuhkan seluruh aktivitas warga yang tinggal di wilayah yang terkena banjir. Akibatnya banyak warga mengeluh akibat bencana banjir tersebut, bukan hanya mengalami kerugian materi, tapi juga keluhan baik fisik bahkan psikis.

Anak-anak sebagai bagian dari komponen masyarakat perlu mendapat perhatian. Anak-anak perlu mendapatkan bekal mengenai pengembangan diri agar menjadi anak yang resilien. Kurang lebih sebanyak 60 anak tinggal dilingkungan yang terkena bencana banjir dan kurang lebih sebanyak 30 anak diantaranya mengalami trauma pasca bencana. Bencana terkadang tidak dapat dihindari, oleh karena itu kemampuan untuk bisa beradaptasi dalam keadaan sulit sangatlah diperlukan.

Adapun penelitian lainnya menunjukkan bahwa terdapat perbedaan skor resiliensi yang signifikan antara kelompok eksperimen dan kelompok kontrol setelah diberikan konseling kelompok. Tingkat resiliensi pada kelompok eksperimen lebih tinggi dibandingkan kelompok kontrol, sehingga konseling kelompok dapat meningkatkan resiliensi (Nurdian \& Anwar, 2014). Selanjutnya penelitian yang dilakukan oleh Safitri (2018) ditemukan bahwa Dalam upaya untuk dapat membantu pemulihan trauma yang dialami oleh korban bencana alam yang selamat, konselor perlu memahami kompleksitas permasalahan yang dihadapi oleh klien sebelum memilih metode, teknik, jenis layanan dan pendekatan konseling agar pelayanan konseling bencana yang diberikan dapat bermanfaat. 
Adapun adanya konseling kelompok memberikan kontribusi yang luar biasa dan positif. Seperti penelitian yang dilakukan oleh Muiz \& Miharja (2017) ditemukan bahwa pelaksanaan konseling kelompok yang meliputi faktor konselor, konseli, metode maupun faktor-faktor pendukung sarana maupun fasilitas sudah cukup baik. Setelah diberikan layanan konseling kelompok oleh guru BK, pelajar dapat merubah perilakunya ke arah yang positif.

Berdasarkan latar belakang di atas, dapat diketahui kondisi anak korban banjir pasca bencana banjir. Kondisi ini sangat penting untuk mengetahui tingkat resiliensi anak korban banjir, agar anak mampu menyesuaikan dirinya dengan lingkungan yang ada disekitar pasca terjadinya bencana banjir.

Dari latar belakang di atas, maka permasalahan yang dirumuskan dalam penelitian ini meliputi Bagaimana kondisi anak korban banjir sebelum mengikuti konseling kelompok? Bagaimana proses konseling kelompok dalam meningkatkan resiliensi anak korban banjir? Bagaimana kondisi anak korban banjir setelah mengikuti konseling kelompok?

Metode yang digunakan dalam penelitian ini adalah deskriptif kualitatif, dengan menganalisis hasil pengumpulan data melalui observasi dan wawancara dengan anak korban banjir, pembimbing/ konselor sekolah Rescue serta kepala sekolah Rescue.

\section{LANDASAN TEORITIS}

Teori yang dijadikan landasan dalam penelitian ini adalah teori konseling kelompok untuk meningkatkan resiliensi anak.Istilah konseling kelompok mengacu kepada penyesuaian rutin atau pengalaman perkembangan dalam lingkup kelompok. Konseling kelompok difokuskan untuk membantu klien mengatasi problem dan perkembangan kepribadiannya (Marianne, 2011: 275).Adapun pengertian lain menurut pendapat Chodijah (2016: 17):

"Konseling adalah pertalian timbal balik antara dua orang individu, seseorang (konselor) membantu yang lain (konseli), untuk lebih baik memahami dirinya dalam hubungannya dengan masalah-masalah hidup yang dihadapinya pada waktu itu dan pada waktu yang akan datang."

Konseling kelompok menurut Natawidjaja bersifat pencegahan, dalam arti bahwa klien yang bersangkutan mempunyai kemampuan berfungsi secara wajar dalam masyarakat, tetapi mungkin memiliki suatu titik lemah dalam kehidupannya sehingga menganggu kelancaran berkomunikasi dengan orang lain (Natawidjaja, 1987: 14).

Dari pendapat para ahli di atas dapat disimpulkan bahwa konseling 
kelompok merupakan suatu proses pemberian bantuan dengan memanfaatkan dinamika kelompok guna mengetahui konsep diri dari masing-masing anggotanya. Dengan lingkungan yang kondusif dapat memberikan kesempatan bagi para anggotanya untuk saling menerima dan memberi ide, perasaan, dukungan maupun bantuan bagi anggota lainnya, serta terdapat hubungan konseling yang hangat, terbuka, permisif dan penuh keakraban. Hal ini merupakan upaya individu untuk membantu individu agar dapat menjalani perkembangannya dengan lebih lancar, upaya itu bersifat preventif dan perbaikan. Sebab, dalam konseling kelompok juga ada pengungkapan dan pemahaman masalah, penelusuran sebab-sebab timbulnya masalah, upaya pemecahan masalah, kegiatan evaluasi dan tindak lanjut. Dengan lingkungan yang seperti ini, seseorang bisa menilai seperti apa konsep diri yang dimilikinya.

Prayitno membedakan tujuan konseling kelompok berdasarkan tujuan umum dan tujuan khusus. Tujuan umum konseling kelompok adalah berkembangnya kemampuan sosialisasi seseorang. Sementara tujuan khususnya adalah terfokus pada pembahasan masalah pribadi peserta kegiatan konseling (Prayitno, 1995: 2). Shertzer dan Stone menyatakan bahwa tujuan dari konseling kelompok adalah mengembangkan pikiran dan perasaan klien agar mampu memahami dan mengatasi problem yang dihadapi diri sendiri (Hastuti, 2004: $559)$.

Fungsi bimbingan dan konseling ditinjau dari kegunaan dan manfaat, ataupun keuntungan-keuntungan apa yang diperoleh melalui pelayanan tersebut. Fungsi-fungsi itu banyak dan dapat dikelompokkan menjadi lima fungsi pokok, yaitu: a) Fungsi pemahaman, fungsi bimbingan dan konseling yang akan menghasilkan pemahaman tentang sesuatu oleh pihak-pihak tertentu sesuai dengan kepentingan pengembangan konseli. b) Fungsi pencegahan, fungsi bimbingan dan konseling yang akan menghasilkan tercegahnya atau terhindarnya konseli dari berbagai permasalahan yang mungkin timbul yang akan mengganggu, menghambat, ataupun menimbulkan kesulitan, kerugian-kerugian tertentu dalam proses perkembangannya. c) Fungsi pengentasan, istilah fungsi pengentasan ini digunakan sebagai pengganti istilah fungsi kuratif atau fungsi terapeutik dengan arti pengobatan atau penyembuhan. d) Fungsi pemeliharaan dan pengembangan, fungsi bimbingan dan konseling yang akan menghasilkan terpeliharanya dan terkembangnya beberapa potensi dan kondisi positif konseli dalam rangka perkembangan dirinya secara terarah, mantap, dan berkelanjutan. e) Fungsi advokasi, fungsi bimbingan dan konseling yang akan menghasilkan pembelaan (advokasi) terhadap konseli dalam rangka upaya pengembangan seluruh potensi secara optimal.

Proses konseling kelompok memiliki empat tahap yaitu:Tahap Awal 
(Beginning Stage), pada tahap awal ini konseling lebih berfokus pada upaya membentuk dan mempersiapkan kelompok dalam memasuki proses konseling. Tahap awal bertujuan untuk memfasilitasi terbentuknya kelompok, terjadinya kontrak dan tujuan kelompok, terdistribusikannya tugas kelompok, terciptanya batasan, terciptanya hubungan positif antar anggota kelompok.Tahap Transisi (Trasition Stage), tahap ini bertujuan untuk tercapainya kesepakatan-kesepakatan yang berlaku di dalam kelompok, terbentuknya kesiapan dalam mengambil resiko, tersusunnya agenda kegiatan, meningkatkan keakraban antar anggota kelompok, meningkatkan apresasi terhadap orang lain, hubungan emosional yang lebih intensif, kesiapan menerima tugas. Tahap Kinerja (Performing Stage), tahap ini bertujuan untuk terbentuknya tim kerja yang produktif, terjadinya proses pelepasan ketegangan dan pencerahan (insight), terciptanya kesempatan untuk pengembangan diri terciptanya "honey moon" antar anggota. Tahap Penutupan (Termination Stage), tahap terminasi bertujuan untuk meninjau kembali dan meringkas pengalaman kelompok, menilai pertumbuhan anggota, perubahan terhadap prestasi, menyelesaikan permasalahan, menjalankan perubahan dalam kehidupan sehari-hari.

Landasan teori selanjutnya yaitu resiliensi korban banjir, menurut R-G Reed (Nurinayanti, 2011: 93) mendefinisikan resiliensi sebagai kapasitas atau kemampuan untuk beradaptasi secara positif dalam mengatasi pemasalahan hidup yang signifikan. Resiliensi merupakan konstruk psikologi yang diajukan oleh para ahli behavioral dalam rangka usaha untuk mengetahui, mendefinisikan dan mengukur kapasitas individu untuk tetap bertahan dan berkembang pada kondisi yang menekan (adverse conditions) dan untuk mengetahui kemampuan individu untuk kembali pulih (recovery) dari kondisi tekanan (McCubbin, 2001: 21). Secara sederhana Jackson dan Watkin mendefinisikan resiliensi sebagai kemampuan untuk beradaptasi dan tetap teguh dalam situasi sulit.

Ada tujuh aspek dari resiliensi (Reivich, 2002: 36-46) aspek-aspek tersebut ialah: a) Regulasi emosi (emotional regulation), pengaturan emosi diartikan sebagai kemampuan untuk tetap tenang dalam kondisi yang penuh tekanan. b) Kontrol impuls (impulse control), kontrol impuls berkaitan erat dengan regulasi emosi. Individu dengan kontrol impuls yang kuat, cenderung memiliki regulasi emosi yang tinggi, sedangkan individu dengan kontrol emosi yang rendah cenderung menerima keyakinan secara impulsive. c) Optimisme (Optimism), individu yang resilien adalah individu yang optimis. d) Kemampuan menganalisis masalah (causal analysis), merupakan istilah yang digunakan untuk merujuk pada kemampuan diri individu secara akurat mengidentifikasi penyebab-penyebab dari permasalahan mereka. e) Empati (empathy), menggambarkan sebaik apa seseorang dapat membaca petunjuk dari orang lain berkaitan dengan kondisi 
emosional orang tersebut. f) Efikasi Diri (self efficacy), efikasi diri menggambarkan keyakinan seseorang bahwa ia dapat memecahkan masalah yang dialaminya dalam keyakinan seseorang terhadap kemampuannya untuk mencapai kesuksesan. g) Pencapaian (reaching out), menggambarkan kemampuan individu untuk mencapai keberhasilan.

Ada lima determinan dari resiliensi yang harus dimiliki oleh setiap individu supaya bisa menjadi resilien, antara lain: 1) Keterampilan Interpersonal, merupakan keterampilan yang dipelajari ataupun bawaan pada diri seseorang yang dapat memfasilitasi kemampuannya dalam berinteraksi secara positif dan efektif dengan orang lain. 2) Kompetensi, diartikan sebagai bakat dan keterampilan yang dimiliki oleh seseorang dan memberikan kontribusi terhadap kemampuannya untuk memiliki resiliensi pada masa dewasa. 3) Self-regard yang tinggi, penerimaan diri yang positif yaitu kemampuan seseorang untuk mengubah pikiran yang negatif menjadi pikiran yang positif terhadap diri mereka. 4) Spiritualitas, spiritualitas dan religiusitas, keduanya adalah komponen yang penting bagi resiliensi seseorang. 5) Situasi kehidupan yang bermanfaat, meskipun tidak semua peristiwa kehidupan bersifat positif, namun bagi indvidu baik peristiwa- peristiwa yang negatif ataupun positif mampu menantang individu untuk menjadi lebih kuat dan memiliki empati terhadap kehidupan orang lain.

\section{HASIL DAN PEMBAHASAN}

Letak Kecamatan Baleendah cukup strategis. Secara astronomis Kecamatan Baleendah terletak pada koordinat 7o 13'-7o 71' LS dan 107o 31'-107o40" BT. Sedangkan secara geografis kecamatan yang pernah menjadi pusat pemerintahan kabupaten hingga tahun 1986 ini berada ditengah wilayah kabupaten Bandung, dengan wilayah bagian timur didominasi oleh perbukitan sedangkan pada bagian barat merupakan daratan. Wilayah kecamatan Baleendah dikelilingi oleh 5 kecamatan lain yang masih merupakan wilayah administratif kabupaten Bandung, dengan batas wilayah utara: Kecamatan Dayeuh Kolot dan Bojong Soang, barat: Kecamatan Katapang, selatan: Kecamatan Pameungpeuk dan Arjasari, dan timur: Kecamatan Ciparay.

Dengan ketinggian wilayah bervariasi antara 600m sampai $715 \mathrm{~m}$ di atas permukaan laut sebagian besar wilayahnya merupakan daratan dan perbukitan dengan suhu udara berkisar antara $24^{\circ}-32^{\circ} \mathrm{C}$. Terdapat dua sungai yang sangat mempengaruhi kehidupan masyarakat kecamatan Baleendah yaitu sungai Citarum dan sungai Cisangkuy. Kedua sungai ini dimanfaatkan oleh petani setempat sebagai sumber pengairan pertanian khususnya padi sawah, namun di musim hujan seringkali kedua sungai ini meluap dan menyebabkan banjir di tiga wilayah desa/kelurahan di Baleendah (Arsip Kecamatan Baleendah, 2013). 
Secara umum iklim di kecamatan Baleendah sama dengan wilayah lain di pulau Jawa yang mengenal dua musim yaitu musim hujan dan musim kemarau. Kondisi cuaca selama tahun 2012 di kecamatan Baleendah cukup fluktuatif di mana curah hujan di kecamatan Baleendah tergolong rendah yaitu $1.856 \mathrm{~mm}$ pertahun dengan rata-rata 10 hari hujan per bulan.

Fenomena banjir tahunan di Kabupaten Bandung ternyata sudah terjadi bahkan sejak awal abad 19. Sedikit yang tahu jika sebenarnya Ibukota Bandung sebagai Kota Klasik dulunya berada di daerah Krapyak (Dayeuhkolot sekarang). Namun akibat lokasi di selatan Kota Bandung ini sering terendam banjir maka Bupati Bandung ketika itu, R.A. Wiranatakusumah II, tahun 1810 memindahkan ibukota kabupaten ke wilayah Bandung tengah, yang bertahan hingga saat ini. Hingga saat ini, banjir akibat luapan Sungai Citarum masih rutin terjadi tiap musim penghujan datang. Daerah Dayeuhkolot dan sekitarnya pun tak pernah luput terendam banjir. Ironisnya lagi, sejak direndam banjir justru masalah yang timbul akibat banjir makin tahun menjadi lebih kompleks.

Hasil penelitian ini menemukan hasil kondisi anak korban banjir sebelum mengikuti kegiatan konseling kelompok, proses konseling kelompok dalam meningkatkan resiliensi anak korban banjir, dan kondisi anak korban banjir setelah mengikuti kegiatan konseling kelompok.

Kondisi Anak Korban Banjir Sebelum Mengikuti Konseling Kelompok

Kondisi anak-anak korban banjir di barak pengungsian Baleendah sebelum mengikuti kegiatan koseling kelompok yang diperoleh dari data observasi, wawancara dan catatan lapangan menunjukan tingkat resiliensi yang rendah. Jika dilihat dilapangan secara langsung, untuk tingkat stress dan cemas pada anakanak korban banjir sekitar 30\%, dikarenakan mereka sudah terbiasa menghadapi bencana banjir ini. Namun anak-anak korban banjir ini membutuhkan tempat yang lebih nyaman yang bebas dari banjir. Di mana anak-anak korban bencana banjir yang berada di barak pengungsian cenderung pendiam, tidak mau berbaur dengan lingkungan sekitar, bahkan tidak sedikit dari mereka yang masih merasa takut atas kejadian yang menimpanya. Sebagian besar anak-anak pernah memiliki pengalaman tenggelam akibat bencana banjir. Sehingga anak-anak korban banjir ini membutuhkan tempat yang lebih nyaman yang jauh dari banjir (Hasil Observasi dan Wawancara dengan Pak Ranggi, 28 Februari 2018).

Anak-anak korban banjir merasa ketakutan setiap kali terjadi banjir, mereka merasa bahwa kejadian banjir ini dikarenakan orangtua mereka yang memilih tinggal ditempat yang langganan banjir. Mereka merasa tidak akan pernah bisa memiliki rumah yang nyaman untuk ditinggali karena diwilayah sekitar rumahnya juga sama-sama terendam banjir. Bahkan mereka menjadi 
sangat malas untuk bersekolah karena sekolah mereka juga yang terendam banjir. Walaupun banjir sudah surut, terkadang motivasi anak-anak korban banjir untuk bersekolah tetap saja rendah karena ketakutan mereka apabila banjir tiba-tiba melanda sekolah mereka disaat mereka sedang belajar di sekolah (Hasil Wawancara dengan anak korban banjir, 28 Februari 2018).

Dalam kondisi seperti ini maka para korban banjir perlu memiliki kemampuan untuk dapat melanjutkan hidup setelah mengalami tekanan yang berat akibat bencana alam atau dengan kata lain mereka harus mampu beradaptasi dan tetap teguh dalam situasi sulit(Taufiq, 2014: 74).

Tabel 1. Kondisi Resiliensi AnakKorban Banjir Sebelum Mengikuti Layanan Konseling Kelompok

\begin{tabular}{|c|c|}
\hline Aspek Resiliensi & Resiliensi Anak \\
\hline \multirow[t]{3}{*}{ Regulasi emosi } & $\begin{array}{l}\text { Anak-anak korban banjir merasa ketakutan setiap kali } \\
\text { banjir datang }\end{array}$ \\
\hline & Takut untuk berangkat sekolah \\
\hline & Takut tidak selamat karena adanya banjir \\
\hline \multirow[t]{3}{*}{ Kontrol impuls } & Cenderung jadi pendiam \\
\hline & Mudah panik dan menangis karena ketakutan \\
\hline & Mudah marah dan merasa tidak nyaman \\
\hline Optimisme & $\begin{array}{l}\text { Berpikir kalau tidak akan pernah memiliki rumah yang } \\
\text { nyaman untuk ditinggali }\end{array}$ \\
\hline \multirow[t]{3}{*}{$\begin{array}{l}\text { Kemampuan } \\
\text { menganalisis masalah }\end{array}$} & $\begin{array}{l}\text { Tidak mengerti dengan apa yang dirasakannya saat terjad } \\
\text { bencana banjir }\end{array}$ \\
\hline & $\begin{array}{l}\text { Tidak tahu harus melakukan apa saat terjadi bencana } \\
\text { banjir }\end{array}$ \\
\hline & $\begin{array}{l}\text { Mereka merasa bahwa ini adalah kesalahan orangtua } \\
\text { mereka yang memiliki rumah di wilayah rawan banjir }\end{array}$ \\
\hline \multirow[t]{3}{*}{ Empati } & $\begin{array}{l}\text { Tidak ingin bergaul atau bersosialisasi dengan lingkungan } \\
\text { sekitarnya }\end{array}$ \\
\hline & $\begin{array}{l}\text { Tidak ingin berbicara dengan lingkungan sekitar kecuali } \\
\text { dengan orangtuanya saja }\end{array}$ \\
\hline & Tidak peduli terhadap lingkungan sekitar \\
\hline \multirow[t]{3}{*}{ Efikasi diri } & Merasa tidak percaya diri saat melakukan sesuatu hal \\
\hline & Tidak ingin mencoba sesuatu hal yang baru \\
\hline & Tidak ingin mengerjakan PR sekolah \\
\hline
\end{tabular}

Irsyad : Jurnal Bimbingan, Penyuluhan, Konseling, dan Psikoterapi Islam 6(3)(2018) 305-324 
Pencapaian Malu karena tinggal sementara di barak pengungsian

bersama orang banyak

Lebih nyaman untuk menjadi penyendiri dan tidak ingin

berbaur dengan lingkungan sekitarnya

Tidak berani melakukan sesuatu yang ingin di lakukannya

Sumber : Hasil Observasi dan Wawancara dengan anak korban banjir pada tanggal 28 Februari 2018

\section{Proses Konseling Kelompok dalam Meningkatkan Resiliensi Anak Korban Banjir}

Trauma Healing adalah kegiatan yang dilakukan perorangan atau tim dengan metode tertentu bertujuan untuk menyembuhkan atau meringankan beban yang menggoncangkan jiwa seseorang atau kelompok tertentu akibat bencana alam seperti banjir, longsor, kecelakaan transportasi dan lain sebagainya. Trauma healing sangatlah penting, melihat banyak dari korban bencana alam mengalami trauma dan ketakutan yang berlebih ketika mendengar suara-suara yang menyerupai gaung, getaran atau semacamnya. Trauma healing lebih diutamakan pada anak-anak dan lansia, yang biasanya mengalami trauma paling kuat, baik stress maupun depresi.

Trauma healing seharusnya dilakukan secara teratur agar dapat membangun kembali mental para korban. Kegiatan trauma bealing yang paling cocok diberikan pada anak-anak korban ialah bentuk kegiatan layanan konseling kelompok.Trauma bealing yang diberikan kepada anak-anak korban bertujuan untuk memulihkan kondisi mental nya dalam kata lain agar mereka mampu melupakan kejadian-kejadian yang terjadi pada masa lampau, sehingga membuat mereka lebih siap apabila bencana kembali datang. Kegiatan trauma healing yang diberikan pada anak-anak tentunya berbeda dengan yang diberikan pada orang dewasa.

Sekolah Rescue merupakan forum untuk para relawan bencana untuk dapat memberikan pertolongan dalam berbagai bencana dan bahaya. Sekolah Rescue menjadi forum untuk memberikan trauma healing pada korban bencana. Program trauma healing ini menggunakan metode konseling kelompok untuk meningkatkan resiliensi anak korban bencana banjir. Anak-anak korban yang mengikuti kegiatan konseling kelompok sudah mengalami beberapa perubahan dalam segi emosional dan perilaku yang otomatis meningkatkan resiliensi anak korban bencana banjir.

Pelaksanaan konseling kelompok di barak pengungsian terbilang baik untuk anak-anak korban banjir hanya saja terdapat beberapa kesulitan untuk 
pelaksanaannya dalam segi waktu dan tempat pelaksanaannya. Layanan konseling kelompok yang ditujukan untuk korban bencana alam apabila dilihat dari segi waktu sangat butuh waktu yang panjang, sedangkan dari segi fokus lebih memerhatikan pada satu masalah yaitu trauma yang dirasakan oleh korban bencana alam. Dilihat dari segi aktifitas lebih banyak melibatkan banyak orang dalam membantu korban dan yang paling banyak aktif adalah konselor. Dan dilihat dari segi tujuan, lebih menekankan pada pulihnya kembali para korban pada keadaan sebelum trauma dan mampu menyesuaikan diri dengan keadaan lingkungan yang baru (Kottman, 1995).

Konseling kelompok merupakan proses antar pribadi yang dinamis, terpusat pada pemikiran dan perilaku yang sadar dan melibatkan fungsi-fungsi terapi seperti sifat permisif, orientasi pada kenyataan, saling mempercayai, saling pengertian, saling menerima dan mendukung (Satriah, 2015: 37).

Adapun beberapa tahapan umum yang biasa dilakukan oleh pihak terkait pasca bencana banjir sebelum melaksanakan kegiatan konseling kelompok pada anak-anak korban banjir (Hasil Wawancara dengan Pak Ranggi, 28 Februari 2018), yaitu: a) Melakukan assessment target (pengumpulan data). b) Membuat janji dengan pengelola pengungsian untuk meminta perijinan mengenai kegiatan yang akan dilakukan di barak pengungsian.c) Setelah mendapatkan perijinan dari pengelola pengungsian, maka pihak terkait melakukan pengelompokan target yang akan diberikan layanan konseling kelompok dengan kegiatan yang disesuaikan dengan usia dan kondisi target.d) Setelah melakukan pengelompokan target dan mendapatkan jadwal untuk pelaksanaan kegiatan konseling kelompok pada anak-anak korban banjir maka akan diadakan TH kelompok (layanan konseling kelompok) tahap 1. Setelah mendapatkan kepercayaan dari anak-anak korban banjir dalam kegiatan tahap 1 maka kegiatan bisa dilanjutkan ke tahap 2 . e) Di kegiatan tahap 2, pihak terkait mencoba mengetahui tingkatan stress atau cemas yang dialami oleh anak-anak korban banjir setelah mengetahui tingkatan stress atau cemas yang dialami anak-anak korban banjir, maka kegiatan bisa dilanjutkan ke tahap 3. f) Di tahapan ke 3, pihak terkait mencoba mengobati rasa trauma yang dialami anak-anak korban banjir dengan menggunakan metode yang sesuai, akan tetapi memakan waktu minimal 3 hari - 7 hari. g) Dalam kurun waktu 7 hari, kegiatan dikatakan berhasil apabila anak-anak korban banjir kembali pulih pada perilaku normal layaknya anak-anak dan tingkat stress atau cemasnya sembuh. Namun apabila ada anak yang mengalami depresi maka pihak terkait akan merujuk anak tersebut. h) Jika anak-anak korban banjir tidak cocok dengan pembimbing/konselor yang menanganinya maka pihak terkait akan mengalihkannya kepada pembimbing/konselor lain untuk menanganinya agar memudahkan proses penyembuhan trauma atau kecemasan yang dialami oleh 
anak-anak korban banjir. i) Apabila pengungsian berlangsung dalam jangka panjang (setelah 40 hari), maka akan ada pergantian tim untuk menangani para korban.Dengan adanya program layanan konseling kelompok anak-anak korban banjir bisa merasa lebih baik dan berangsur pulih ke keadaan sebelum mengalami trauma atau kecemasan yang alaminya.

Dalam konseling kelompok terdapat beberapa komponen, yaitu: Pertama, konselor, merupakan komponen inti dan faktor pendukung dalam keberhasilan kegiatan proses konseling. Konselor yang baik harus memiliki kemampuan bersikap tenang ketika bersama orang lain, memiliki rasa empati, menciptakan rasa nyaman agar anak-anak korban banjir yang ingin bercerita bisa mendapatkan penanganan yang baik dan tepat. Konselor berperan aktif dalam kegiatan konseling kelompok yang ditujukan untuk anak-anak korban banjir guna meningkatkan resiliensi pada anak-anak korban. Konselor berusaha mengarahkan, memberikan sugesti, saran untuk memulihkan kondisi anak-anak korban banjir pada keadaan sebelum mengalami trauma atau kecemasan pasca bencana banjir.

Konselor berusaha menggunakan keterampilan, kepribadian dan wawasannya untuk menciptakan situasi konseling yang menyenangkan. Menurut Satriah, kualitas pribadi konselor adalah kriteria yang menyangkut segala aspek kepribadian yang amat penting dan menentukan keefektifan konselor jika dibandingkan pendidikan dan latihan yang diperoleh (Satriah, 2015: 39). Sedangkan menurut Virginia ada beberapa karakteristik konselor, antara lain: (1) Resource person, konselor adalah orang yang banyak mempunyai informasi dan senang memberikan dan menjelaskan informasinya, (2) Model of communication, bagus dalam berkomunikasi, mampu menjadi pendengar yang baik dan komunikator yang terampil (Virginia, 1967).

Setelah berhasil menciptakan proses konseling yang menyenangkan, konselor berusaha untuk memberikan alternatif-alternatif yang sesuai dengan kondisi dan situasi konseli. Konseling kelompok dengan metode permainan untuk anak-anak korban banjir terbilang lebih efektif karena anak-anak cenderung lebih menyukai permainan dengan sebayanya (Hasil Wawancara dengan Pak Adi, 28 Februari 2018).

Konselor juga menjadi fakor penentu bagi pencapaian konseling yang efektif, di samping faktor pengetahuan tentang dinamika perilaku dan keterampiloan terapeutik atau konseling, hal ini juga merupakan faktor pendukung bagi tercapainya suatu profesi konselor yang professional. Kegiatan konseling yang dilakukan oleh setiap konselor tentunya tidak akan terlepas dari berbagai aspek penting mengenai komunikasi. Suatu komunikasi yang baik tidak 
akan tercapai bila tidak adanya rasa saling percaya antara kedua belah pihak. Ketercapaian rasa saling percaya ini dapat tercapai dengan pengetahuan/keterampilan dan kepribadian yang dimiliki oleh konselor.

Kedua, konseli, karakteristik konseli yang disebutkan dalam buku konseling kelompok menyatakan bahwa keadaan konseli berubah-berubah pola kegiatan, gelisah, tanpa arah dan mencari motivasi untuk meneruskannya. Kadang-kadang timbul perasaan bersalah terhadap kejadian atau kegagalan yang ia alami, atau menyalahkan diri sendiri secara berlebihan. Karakter konseli yang seperti itu menjadi karakteristik terbanyak yang ada di barak pengungsian (Hasil Wawancara dengan Pak Adi, 28 Februari 2018).Dengan mengikuti layanan konseling kelompok yang diadakan oleh pihak terkait, membuat anak-anak korban banjir yang memiliki karakteristik tersebut merasa termotivasi untuk tidak berlaku demikian.

Ketiga, materi konseling kelompokyang diberikan biasanya disesuaikan dengan permasalahan yang dialami oleh anak-anak korban banjir. Namun materi yang biasa disampaikan oleh pembimbing/konselor biasanya mengenai motivasi untuk anak-anak (Hasil Wawancara dengan Pak Ranggi, 28 Februari 2018).

Keempat, metode yang digunakan pada kegiatan konseling kelompok ialah metode menggambar, bermain, bercerita, menonton film yang bertemakan motivasi untuk anak dan wawancara secara santai agar anak tidak merasa jenuh dan mau bercerita mengenai perasaannya saat tertimpa bencana banjir (Hasil Observasi dan Wawancara dengan Pak Ranggi, 28 Februari 2018).

Kelima, media konseling kelompok salah satu hal penting yang turut mempengaruhi keberhasilan layanan konseling kelompok di barak pengungsian yaitu media yang menunjang kegiatan konseling kelompok yaitu alat tulis seperti kertas HVS dan pensil; mainan anak-anak, serta audio visual (Hasil Observasi dan Wawancara dengan Pak Ranggi, 28 Februari 2018).

Keenam, waktu pelaksanaan konseling kelompokdilaksanakan satu hari setelah anak-anak korban bencana banjir berada di pengungsian. Kegiatan konseling kelompok ini tidak bisa dilaksanakan hanya satu kali pertemuan saja, tetapi harus secara kontinu. Kegiatan konseling kelompok untuk anak-anak korban bencana banjir dilaksanakan dalam kurun waktu 3 sampai 7 hari.Namun ada beberapa kesulitan dalam waktu pelaksanaan kegiatan konseling kelompok di barak pengungsian. Hal ini dikarenakan waktu sekolah anak-anak yang berbeda, terkadang ada anak yang pulang sekolah di siang hari ada juga yang pulang di sore hari, sehingga sulit untuk mengumpulkan anak-anak korban banjir untuk melaksanakan konseling kelompok. Sehingga pelaksanaan konseling kelompok pada anak-anak bisa dilaksanakan pada hari libur anak-anak sekolah atau pada 
saat semua anak-anak korban banjir sudah pulang sekolah (Hasil Wawancara dengan Pak Adi, 28 Februari 2018).

Ketujuh, tempat pelaksanaan konseling kelompoktentunya harus membuat anak-anak korban banjir yang akan menjadi peserta merasa nyaman sehingga kegiatan yang dilaksanakan berjalan dengan lancar. Akan tetapi untuk beberapa titik pengungsian masih banyak yang belum memiliki tempat khusus yang nyaman untuk melaksanakan kegiatan konseling kelompok. Sehingga untuk melaksanakan kegiatan konseling kelompok, tempat yang digunakan biasanya dihalaman atau diluar barak pengungsian. Hal ini dilakukan agar anak-anak korban banjir merasa nyaman saat mengikuti kegiatan yang dilaksanakan dan tidak mengganggu para korban banjir lainnya yang sedang beristirahat didalam barak pengungsian (Hasil Observasi dan Wawancara dengan Pak Adi, 28 Februari 2018).

Proses konseling kelompok untuk anak-anak korban banjir bencana banjir bertujuan untuk memulihkan trauma atau kecemasan yang dialami anak dan meningkatkan resiliensi anak. Ada beberapa tahapan dalam proses konseling kelompok untuk anak-anak korban banjir bencana banjir (Hasil Observasi dan Wawancara dengan Pak Adi, 28 Februari 2018) :Tahap awal dalam konseling kelompok merupakan tahap persiapan, mempersiapkan media yang akan digunakan dalam proses kegiatan konseling kelompok berupa tempat, alat-alat yang menunjang untuk melakukan konseling kelompok. Selanjutnya tahap perkenalan dan membangun rapport kepada konseli. Pada fase ini merupakan titik penentu pembangunan kepercayaan konseli terhadap konselornya sehingga membangun hubungan yang baik. Dalam pelaksanaan proses konseling kelompok yang peneliti amati di barak pengungsian bersifat informal namun tetap menerapkan unsur-unsur konseling.

Ketika konselor mengumpulkan seluruh konseli (anak-anak korban banjir), konselor menyambut anak-anak korban banjir dengan ramah serta memberikan senyuman. Disamping itu konselor menciptakan suasan akrab dan bersahabat agar terciptanya rapport dalam proses konseling kelompok agar anak-anak korban banjir merasa nyaman, selanjutnya konselor mulai membentuk dan mempersiapkan kelompok untuk memulai kegiatan konseling kelompok. Tahap awal bertujuan untuk memfasilitasi terbentuknya kelompok, terjadinya kontrak dan tujuan kelompok, terdistribusikannya tugas kelompok, terciptanya batasan, terciptanya batasan, terciptanya hubungan positif antar anggota kelompok.

Tahap Transisi, tahap ini bertujuan untuk tercapainya kesepakatankesepakatan yang berlaku didalam kelompok, terbentuknya kesiapan dalam mengambil resiko, tersusunnya agenda kegiatan untuk meningkatkan keakraban 
antar anggota kelompok, meningkatkan apresiasi terhadap orang lain, hubungan emosional yang lebih intensif, dan kesiapan menerima tugas.

Pada tahap ini juga di mana konselor mengeksplorasi permasalah rendahnya tingkat resiliensi anak-anak korban banjir dengan cara: Meminta konseli untuk menggambarkan kejadian traumatik yang mereka alami, apa yang mereka lihat dan dengar; Meminta konseli untuk menggambarkan reaksi kognitifnya terhadap peristiwa traumatik tersebut; Menolong konseli mengenali emosi-emosi yang menyertai kejadian tersebut; dan menanyakan reaksi-reaksi konseli setelah perisitiwa traumatik itu terjadi.

Tahap Kinerja, tahap ini bertujuan untuk terbentuknya tim kerja yang produktif, terjadinya proses pelepasan ketegangan dan pencerahan (insight), terciptanya kesempatan untuk pengembangan diri.Pada tahap ini juga pencarian solusi untuk konseli terhadap permasalahan rendahnya tingkat resiliensinya, yang diawali dengan : a) Menginformasikan kepada anak-anak korban banjir bahwa trauma yang diceritakan adalah suatu bentuk dari memori. trauma cenderung membuat memori menjadi beku dan membekukan konseli sehingga sering membuat mereka tidak mampu mengambil tindakan lebih lanjut. Konselor memiliki tugas untuk me-reframe flashback dalam upaya penyembuhan dari pengalaman traumatik agar mereka dapat mengembangkan hidupnya lebih lanjut. Membuat konseli menyadari kejadian traumatiknya adalah sangat penting sebagai suatu transisi kehidupan dan hal itu normal saja. b) Konseli diajak untuk berani menghadapi perasaannya yang ditekan akibat trauma. Hal ini bukan persoalan mudah karena kebanyakan mereka tidak mau atau takut untuk merasakan emosi itu kembali. Tapi yang terpenting bagi konseli adalah menghadapi emosi-emosi negatifnya (marah, cemas, takut, sedih dan berduka). c) Konseli diajak untuk mampu membicarakan kejadian traumanya dengan orang lain, membaca tulisantulisan atau melihat televisi yang berkaitan dengan kejadian traumanya. Hal ini akan memberikan pemahaman yang lebih baik mengenai kejadian traumatiknya dan mampu mengurangi perasaan-perasaan negatifnya. d) Menolong konseli untuk mengidentifikasi pemicu reaksi-reaksi traumanya dan mengajari bagaimana mengendalikan. Cara-cara yang bisa dilakukan adalah dengan mengajari konseli relaksasi, menarik nafas dalam-dalam dengan diikuti self-talk.

Tahap Penutup, bertujuan untuk meninjau kembali dan meringkas pengalaman kelompok, menilai pertumbuhan anggota, perubahan perilaku konseli, menyelesaikan permasalahan, menjalani perubahan dalam kehidupan sehari-hari. Pada tahapan ini juga konselor mencoba untuk me-review dan megevaluasi hasil konseling kelompok dan menentukan langkah selanjutnya untuk penanganan traumatik konseli.

Dalam proses pelaksanaan yang digunakan untuk meningkatkan resiliensi 
pada anak korban banjir dikatakan bahwa konseling kelompok sangat sesuai untuk digunakan. Adapun salah satu sumber mengatakan bahwa untuk menangani reaksi-reaksi yang ringan itu selain para konselor dapat memanfaatkan teknik konseling individu, bisa juga menggunakan teknik konseling kelompok (alamiah atau buatan). Misalnya membentuk kelompok sharing pengalaman. Perlu juga anggota kelompok dilatih untuk bersikap empati dan mendengarkan. Kalau terbiasa menggunakan teknik kursi kosongnya pendekatan Gestlat juga sangat bermanfaat. Tak jarang kaum lelaki menahan tangisnya ketika peristiwa tragis itu terjadi. Dalam hal ini konselor bias mendorong mereka dan mempersilahkan untuk menangis sepuas-puasnya (Imanudin, 2010: 981).

\section{Kondisi Anak Korban Banjir Setelah Mengikuti Konseling Kelompok}

Program konseling kelompok terhadap anak-anak korban banjir merupakan proses pemberian bantuan kepada anak-anak korban banjir yang memiliki masalah mengenai rendahnya resiliensi anak akibat trauma yang dialami dari peristiwa yang terjadi sehingga anak-anak korban banjirmampu menghadapi permasalahannya dan dapat menyelesaikan tugas perkembangannya dengan baik.

Dengan demikian setelah mengikuti kegiatan konseling kelompok, secara perlahan resiliensi anak-anak korban banjir mulai meningkat. Sedikit-demi sedikit berubah menjadi lebih baik dari segi emosional dan perilaku (Hasil Observasi dan Wawancara dengan Pak Ranggi, 28 Februari 2018). Adapun kondisi resiliensi anak-anak korban banjir setelah mengikuti kegiatan konseling kelompok :

Tabel 2. Kondisi Resiliensi Anak Korban Banjir Setelah Mengikuti Layanan Konseling Kelompok

\begin{tabular}{|c|c|}
\hline Aspek Resiliensi & Resiliensi Anak \\
\hline \multirow[t]{3}{*}{ Regulasi emosi } & $\begin{array}{l}\text { Anak-anak korban banjir sudah tidak merasa takut } \\
\text { karena peristiwa banjir }\end{array}$ \\
\hline & $\begin{array}{l}\text { Anak-anak korban banjir sudah berani dan bersemangat } \\
\text { untuk berangkat ke sekolah }\end{array}$ \\
\hline & Anak-anak korban banjir menjadi ceria, senang \\
\hline \multirow[t]{3}{*}{ Kontrol impuls } & Menjadi ceria, senang, tidak murung lagi \\
\hline & Menjadi lebih tenang dalam menghadapi permasalahan \\
\hline & Tidak mudah marah \\
\hline Optimisme & $\begin{array}{l}\text { Yakin akan bisa tinggal di rumah yang nyaman dan bebas } \\
\text { banjir }\end{array}$ \\
\hline
\end{tabular}


Kemampuan menganalisis masalah

Empati

Efikasi diri

Pencapaian
Mulai bisa menjelaskan apa yang dirasakan saat peristiwa terjadi

Sudah mengetahui harus melakukan apa saat terjadi peristiwa yang sama

Mereka sudah memahami bahwa ini bukanlah kesalahan orangtuanya yang memiliki rumah di wilayah banjir

Mereka sudah memahami bahwa peristiwa tersebut terjadi karena gejala alam

Mulai bergaul atau bersosialisasi dengan lingkungan sekitarnya

Berbicara tidak hanya dengan orangtua tapi dengan lingkungan sekitar juga

Mulai peduli dengan situasi dan kondisi terhadap lingkungan sekitar

Mulai percaya diri saat akan melakukan sesuatu hal

Ingin selalu mencoba sesuatu hal yang baru

Sangat bersemangat untuk mengerjakan PR sekolah

Tidak merasa malu karena tinggal sementara di barak pengungsian dengan banyak orang

Lebih senang berbaur dengan lingkungan sekitar karena senang memiliki banyak teman

Berani melakukan sesuatu yang ingin dilakukannya

Sumber : Hasil Observasi dan Wawancara dengan anak korban banjir, pada tanggal 28 Februari 2018

Sehingga dari hasil penelitian bahwa layanan konseling kelompok pada anak-anak korban banjir dengan tingkat resiliensi yang rendah terdapat peningkatan pada resiliensinya. Adanya perubahan dalam diri konseli bahwa dalam dirinya memiliki kesadaran akan tanggung jawab atas dirinya dan keluarga. Anak-anak korban banjir pun mulai mengurangi rasa cemas yang berlebih dan membangun rasa kepercayaan diri sebagai modal awal untuk menyusun langkahlangkah dalam menggapai cita-citanya. Kegiatan konseling kelompok cocok untuk anak-anak korban banjir karena anak-anak cenderung menyukai bermain dengan sebayanya. Konselor yang lebih aktif berusaha mengarahkan, memberikan sugesti dan memberi saran serta motivasi pada anak-anak korban banjir.

Kondisi resiliensi anak korban banjir yang meningkat setelah mengikuti kegiatan konseling kelompok dapat dikatakan berhasil, hal ini sesuai dengan 
pendapatSofyan Willis yang mengatakan indikator keberhasilan konseling adalah menurunnya kecemasan konseli, mempunyai rencana hidup yang praktis, pragmatis, dan berguna, dan mengadakan kembali pertemuan untuk mengecek hasil pelaksanaan rencananya (Willis, 2014: 54 ).

\section{PENUTUP}

Berdasarkan hasil temuan, analisis dan pembahasan terhadap data yang dapat dikumpulkan selama penelitian, serta dengan mengacu pada rumusan masalah yang telah dikemukakan pada bagian sebelumnya, maka penulis menyimpulkan bahwa konseling kelompok dalam meningkatkan resiliensi anak korban banjir adalah :

Kondisi anak korban bencana banjir di barak pengungsian mengalami masalah mengenai tingkat resiliensi hidup yang rendah, yakni anak tidak dapat memahami permasalahan apa yang dihadapinya, tidak dapat mengontrol emosinya, tidak memiliki keyakinan untuk dapat menghadapi segala situasi yang terjadi dalam hidupnya, tidak mampu membuat solusi terhadap masalah yang dihadapinya. Beberapa anak bahkan sulit untuk membangun komunikasi dengan orang lain bahkan mereka tidak peduli dengan situasi dan kondisi lingkungan sekitar. Anak-anak korban bencana banjir cenderung menjadi pendiam dan penyendiri saat berada di barak pengungsian.

Proses konseling kelompok dalam meningkatkan resiliensi pada anak korban banjir di barak pengungsian dilakukan oleh seorang pembimbing/konselor yang sudah mendapatkan pelatihan dan sertifikat untuk melakukan terapi trauma healing. Konseling kelompok dalam meningkatkan resiliensi pada anak korban banjir menggunakan teknik permainan dan menggambar yang dilakukan saat semua anak korban banjir sedang berada di barak pengungsian dan dilakukan dihalaman barak pengungsian. Media yang digunakan pun hanya berupa mainan anak, alat tulis, dan audio visual. Materi yang diberikan pembimbing/konselor berupa motivasi agar anak-anak korban banjir lebih bersemangat lagi dalam menyelesaikan masalah yang sedang dihadapinya. Waktu pelaksanaan konseling kelompok pada anak korban banjir dilakukan paling sebentar sekitar 3-7 hari. Namun apabila kondisi anak korban banjir belum menunjukkan perubahan yang baik, maka pelaksanaan konseling kelompok bisa dilaksanakan dalam waktu yang tidak bisa ditentukan. Dengan syarat apabila kegiatan sudah berlangsung lebih dari 40 (dalam jangka panjang) hari maka ada pergantian tim pembimbing/konselor.Dalam kegiatan konseling kelompok untuk anak-anak korban banjir, yang berperan lebih aktif adalah 
pembimbing/konselornya. Bahkan dalam kegiatan ini, lebih banyak melibatkan banyak orang yang berkaitan dan ahli dalam bidang konseling, psikologi, psikoterapi maupun medis.

Hasil konseling kelompok dalam meningkatkan resiliensi pada anak korban banjir di barak pengungsian adalah adanya peningkatan yang dialami oleh anak-anak korban banjir. Konseling kelompok dapat meningkatkan resiliensi anak, seperti anak mulai mampu memahami permasalahan apa yang dihadapinya, dapat mengontrol emosinya, memiliki keyakinan untuk dapat menghadapi segala situasi yang terjadi dalam hidupnya, mampu membuat solusi terhadap masalah yang dihadapinya dan anak-anak korban banjir kembali menjadi gembira, aktif serta bersosialisasi dengan lingkungan sekitar walaupun berada di barak pengungsian. Sehingga dari hasil penelitian bahwa layanan konseling kelompok terhadap anak-anak korban bencana banjir dengan tingkat resiliensi yang rendah terdapat peningkatan dalam resiliensinya.

\section{DAFTAR PUSTAKA}

Chodijah, S. (2016). Pengantar Bimbingan Konseling Pendidikan. Bandung: CV. Mimbar Pustaka.

Ehreinreich, J. H. (2001). Coping With Disaster. A Guidebook to Psychosocial Intervention. Revised Edition. Center for Psychology and Society, State University of New York, 25.

Hastuti, W. (2004). Bimbingan Konseling di Institut Pendidikan. Yogyakarta: Media Abadi.

Imanudin, D (2010). Konseling Paska Bencana dalam ilmu dakwah: Academic Journal Homiletic Studies,5(15), 981.

Marianne, G. R. (2011). Bimbingan dan Konseling. Yogyakarta: Pustaka Pelajar.

McCubbin, L. (2001). Chalange to The Definition of Resilience. Paper presented at The Annual Meeting of The American Psychological Association in San Francisco, 21.

Muiz, G.A., Miharja, S. (2017). Peran Layanan Konseling Kelompok Terhadap Perilaku Agresif Pelajar dalam Irsyad: Jurnal Bimbingan, Penyuluhan, Konseling, dan Psikoterapi Islam 5(2) 203-220.

Natawidjaja, R. (1987). Pendekatan-Pendekatan dalam Penyuluhan Kelompok. Jakarta: Departemen Pendidikan dan Kebudayaan.

Nurdian, M.D., \& Anwar, Z. (2014). Konseling kelompok untuk meningkatkan resiliensi pada remaja penyandang cacat fisik (difable) dalam Jurnal Ilmiah Psikologi Terapan 2(1).

Nurinayanti, A. (2011). Makna Kebersyukuran dan Resiliensi: Telaah Pustaka tentang Pengaruh Kebersyukuran dan Pengaruhnya Terhadap Daya Resiliensi pada Korban Erupsi Merapi DIY 2010. Jurnal Psikologi, 93. 
Prayitno. (1995). Layanan Bimbingan dan Konseling Kelompok (Dasar dan Profil). Jakarta: Gahalia Indonesia.

Rachmat T. E. S. (2014). Gambaran Resiliensi Anak Pasca Bencana Banjir Desa Dayeuhkolot, Kabupaten Bandung, Jawa Barat. Wacana Jurnal Psikologi Vol. 6 No. 11, 74.Buana.

Reivich, S. (2002). The Resilience Factor: 7 Keys to Finding Your Inner Strength and Overcoming Life's Hurdles. New York: Broadway Book.

Safitri, N. (2018). Crisis and Disaster Counseling: Peran Konselor terhadap Korban Yang Selamat Dari Bencana Alam dalam Educational Guidance and Counseling Development Jounal 1(2) 66-76.

Satriah, L. (2015). Bimbingan dan Konseling Kelompok (Seting Masyarakat). Bandung: CV. Mimbar Pustaka.

Virginia. (1967). Bimbingan dan Konseling. Jakarta: Gahalia Indonesia.

Willis, S. S. (2014). Konseling Individual, Teori dan Praktek. Bandung: CV. Alfabeta. 